Virginia Commonwealth University vCU Scholars Compass

2014

\title{
Collaboration and Resistance on the Southwest Frontier: Early Eighteenth-Century Qing Expansion on Two Fronts
}

John Herman

Virginia Commonwealth University, jherman@vcu.edu

Follow this and additional works at: http://scholarscompass.vcu.edu/hist_pubs

Part of the Asian History Commons

Copyright (C) Society for Qing Studies and The Johns Hopkins University Press

\section{Downloaded from}

http://scholarscompass.vcu.edu/hist_pubs/11

This Article is brought to you for free and open access by the Dept. of History at VCU Scholars Compass. It has been accepted for inclusion in History Publications by an authorized administrator of VCU Scholars Compass. For more information, please contact libcompass@vcu.edu. 


\title{
COLLABORATION AND RESISTANCE ON THE SOUTHWEST FRONTIER: EARLY EIGHTEENTH- CENTURY QING EXPANSION ON TWO FRONTS
}

\author{
John Herman, Virginia Commonwealth University
}

In 1715 Qing China (1644-1912) was forced to respond to two separate international events, the Zunghar Mongol threat in Central Eurasia and Japan's decision to limit copper exports to China. The Qing response was immediate. After receiving word that Zunghar forces had attempted to invade Hami (Qomul), a major oasis along the Silk Road, the Kangxi emperor (1654-1722, r. 1661-1722) ordered the mobilization of Qing forces along China's northwest frontier. The Zunghars had grown increasingly agitated by Qing attempts to control Tibetan affairs: in 1705, Kangxi encouraged the Khoshot Mongol leader Lazang Khan (1656?-1717) to occupy Lhasa and purge those who advocated close relations with the Zunghars, and in 1709 the Qing official Heshou (d. 1719) took up residence in Lhasa in a show of support for Lazang Khan. The final straw was Lazang Khan's role in the overthrow and death of the Sixth Dalai Lama in 1706, his selection of a new Sixth Dalai Lama, a person rumored to be his son, and lastly his attempt in 1714 to seize the boy many Tibetans and Mongols believed to be the reincarnation of the Sixth Dalai Lama who died in 1706. This boy, Kelzang Gyatso (1708-57), fled his hometown (Lithang) in the Kham region of Eastern Tibet just prior to the arrival of Lazang Khan's agents, and now in 1715 he was under Qing "protective custody" at the Hongshan monastery near Xining. Kangxi knew the Zunghar assault on Hami was a prelude to a more sustained challenge to the Khoshot-Qing presence in Tibet. ${ }^{1}$

The Qing decision to mobilize forces along its northwest frontier was made at roughly the same time Japan's Tokugawa regime (1600-1868) announced new regulations (Shōtoku shinrei) regarding trade at Nagasaki. One component of these new regulations was a reduction in the amount of copper Chinese merchants could purchase from Japan. The Qing state's two main mints in

1 KXSL, 241:14b-15a; 263:7a-9b; Petech, China and Tibet in the Early XVIIIth Century, 14-24; Perdue, China Marches West, 229-30.

Late Imperial China Vol. 35, No. 1 (June 2014): 77-112

(C) by the Society for Qing Studies and The Johns Hopkins University Press 
Beijing, the Ministry of Revenue's Baoquanju and the Ministry of Works' Baoyuanju, relied heavily on the annual supply of approximately 4 million jin ( 1 jin equals $1.1 \mathrm{lbs}$. or $0.597 \mathrm{~kg}$ ) of Japanese copper to cast coin, the basic currency for daily transactions in much of Qing China. China's economy depended on an adequate supply of coin to meet the currency needs of the people and to maintain the coin-to-silver ratio of 1,000 coins to 1 tael (37.3 grams) of silver. ${ }^{2}$ In response to Japan's decision in 1715, the Qing state sought to reduce the amount of copper content in coin, persuade people to sell old copper wares to the state, prohibit craftsmen from using copper, and even encourage people to pay taxes in coin and copper wares instead of silver. When these measures to ration copper usage proved insufficient, Kangxi and his successor Yongzheng (1678-1735, r. 1723-35) moved to acquire the vast copper deposits located almost entirely on hereditary tusi (native official) lands in southwest China (the provinces of Yunnan, Guizhou, and Sichuan).

This article will examine the dramatic burst in Qing expansion into two different regions during a brief fifteen-year period (1715-30): the Kham territory of Eastern Tibet and tusi-controlled territories in neighboring Sichuan and Yunnan provinces. Previous scholarship has described the Qing response to the expanding Zunghar threat in Central Eurasia as having little or no relationship with the rapid "militarization" of the southwest in the $1720 \mathrm{~s}$, and vice versa. ${ }^{3}$ Yet, beginning in 1715 these two events lay side by side on the emperor's desk and for the next fifteen years Kangxi, Yongzheng, and a multitude of Qing officials strategized how to respond to these two events. ${ }^{4}$ In fact, during these fifteen years many officials posted in Sichuan and Yunnan oversaw both tasks simultaneously, and Beijing regularly rotated officials from one region to the other because of a demonstrated expertise in frontier affairs. ${ }^{5}$ Instead of examining this expansion as separate events, this article proposes an integrated approach that links both the Kham region and southwest China as objects in a

\footnotetext{
2 Gramlich-Oka, "Shogunal Administration of Copper in the Mid-Tokugawa Period (1670-1720),"91-97; Iwasaki, "Genbun dōza-ki no Nagasaki kaidō to Nagasaki bōeki" (The Copper Bureau's Role in the Transport of Nagasaki Copper and Nagasaki Trade during the Genbun Period), 34:1-42; Nakajima, "Shinchō no dōsei ni okeru yōdō to tendō" (Qing dynasty copper administration: Japanese copper and Yunnan copper), 161-77; Ueda, Shinchō shihai to kahei seisaku: Shindai zenki ni okeru seisan kyōkyū seisaku no tenkai (Qing rule and monetary policy: the development of coin supply policy during the early Qing period), 110-20.

3 On the militarization of the southwest during the Yongzheng reign, see Smith, "Ch'ing Policy and the Development of Southwest China"; Giersch, Asian Borderlands, 43-62; Feng, Yongzheng zhuan (Biography of the Yongzheng emperor), 321-57; Weinstein, Empire and Identity in Guizhou, 43-58.

4 I certainly do not suggest that a single vision of Qing empire-building can be found on the emperor's desk or in his communiqués with officials. Students of empires are well aware that much of what is achieved in the name of empire is improvised on the ground between competing interests, both public and private.

Guy, Qing Governors and Their Provinces, 1644-1796; Dai, The Sichuan Frontier and Tibet, 64-90.
} 
coordinated response to two unrelated international events affecting the strategic and economic security of Qing China.

The geographic proximity of Kham to Yunnan and Sichuan led emperor and official alike to consider Kham and the southwest part of a larger strategic region whose diverse populations were susceptible to both instability in Tibet and anti-Qing sentiments. ${ }^{6}$ Not only did the peoples of Kham, southwest Sichuan, and northwest Yunnan participate in extensive trade networks along shared borders, but Qing officials believed a certain cultural affinity existed between these peoples. Thus, Zunghar inroads into Tibet could potentially destabilize the entirety of Qing China's western border, from the Yunnan-Burma border region in the south to the Shaanxi-Sichuan-Amdo region in the north. Moreover, $\mathrm{Wu}$ Sangui's anti-Qing rebellion (1673-81) persisted as a disturbingly fresh memory in China, and rumors of loyalists inspiring nostalgia for Ming rule preoccupied the ruling Manchu elite and their Han Chinese sympathizers. ${ }^{7}$

Second, this integrated approach offers a fresh perspective on the historical process of Qing imperial expansion, and specifically the role of hereditary tusi (native official) offices in this process. Because of the strategic threat posed by the Zunghars in 1715, Qing officials were ordered to secure allies from among the indigenous elite in Kham and to "turn" these indigenous leaders toward Beijing. As John Darwin recently discussed in his examination of the British Empire, one of the most difficult tasks, but also one of the most vital, was settling the terms on which the indigenous peoples and their leaders would become the allies, the clients or the subjects of empire. It is easily forgotten that across much of the world empire was "made" as much if not more by the local auxiliaries that "empire-builders" recruited as by the imperialists themselves. The result was an empire of hybrid components, conflicting traditions, and unsettled boundaries between races and peoples: a source of constant unease as well as extraordinary energy. ${ }^{8}$ Qing expansion into Kham depended on the cooperation of local elites, and in this case the device to lure them toward Beijing was the tusi office. Imperial governance was by necessity a series of compromises, and this was especially true at the empire's edge where the Qing state offered tusi titles and offices, as well as vital military and financial support in return for a declared submission to the Qing throne.

KXSL, 287:14a-b, 19a-20b, 289:4a-5a

Guizhou tongzhi, qianshizhi (Comprehensive gazetteer of Guizhou province, a record of early events), 3:120-21, 147, 149-50. One such loyalist, Huang Ming, was allegedly a commander under Wu Sangui, and since the war's end in 1681 he attracted Han Chinese to his base in the remote border region where Guizhou, Hunan, and Guangxi meet.

8 Darwin, Unfinished Empire, xii. 
As this article will show, Qing officials posted to the southwest during this fifteen-year period were in a very peculiar position. In the last decades of the fourteenth century, the Ming state (1368-1644) used tusi offices to extend its authority into the southwest frontier, and now at the beginning of the eighteenth century the process of state expansion had nearly run its course. Even before 1715 officials posted to the southwest were calling for the elimination of all remaining tusi offices. With the events of 1715 , these calls grew louder. The tusi office, however, was the instrument of choice to expand Qing influence into Kham. In other words, Qing officials posted to Sichuan and Yunnan during this fifteen-year period were authorized to negotiate alliances and grant tusi offices in order to advance the Qing empire into Kham, while at the same time they moved aggressively to eliminate the remaining tusi in order to consolidate civilian control throughout Yunnan and Guizhou. In short, beginning in 1715 both ends of the historical spectrum Peter Perdue describes as the process of Qing imperial expansion existed in the southwest: the initial use of tusi offices to extend Qing influence into Kham, and the elimination of tusi in the southwest in order to establish centralized civilian rule. ${ }^{9}$

Finally, this integrated approach allows us to consider Yongzheng activism in the southwest not solely as an attempt to reclaim land for tax purposes or as a moral drive to impose civilizing institutions upon the indigenous peoples. Nor was this activism purely a reaction to the decline in copper imports from Japan, though the scarcity in copper had much to do with enabling this activism toward tusi in the southwest. Instead, I believe the drive to eliminate tusi offices and erase from the landscape such hybrid features of indirect rule was part of a larger Zunghar-inspired strategic adjustment designed to secure control over the southwest provinces. This approach allows us to appreciate more fully why Qing state activism in the southwest attained such extreme levels of brutality.

The Qing state veiled the elimination of tusi in the southwest by presenting its actions as a moral obligation, a weight borne by those who ruled China. Civilized rule guided by moral truths and an impartial legal system was Beijing's gift to the indigenes in the southwest, a gift the indigenes could not refuse. This rhetoric was not exclusive to the Qing. Ming officials relied on similar rhetorical devices to replace many of the hereditary tusi offices with Chinese civil institutions. Such rhetoric assured those officials that their task was just, even when they seized indigene lands, confiscated indigene resources, and eliminated indigene resistance. This rhetoric not only motivated the colonizer to act, it also encouraged subsequent historians to erase from their narratives the more

Perdue, China Marches West, 310-14. 
disconcerting aspects of Qing imperial expansion. As Nicholas Dirks points out at the end of The Scandal of Empire, "When imperial history loses any sense of what empire meant to those who were colonized, it becomes complicit in the history of empire itself." ${ }^{10}$ Given the brutality of what transpired in Yunnan and Guizhou during the Yongzheng reign, the end of the empire building process in the southwest proved to be just as violent, if not more so, than what transpired in Kham at the same time.

\section{Tusi and the Annexation of Kham}

Prior to 1715 the towns along the Darzêdo-Lhasa route in the Kham region of Eastern Tibet were under the nominal authority of officials appointed from Lhasa. These officials administered the Tibetan postal system, collected taxes, supervised trade relations between Sichuan and Tibet, and tried, as best they could, to ensure safe passage for religious pilgrims making their way to and from Lhasa. But their control over the immense territory of Kham was never entirely secure. The peoples of this region were (and still are) staunchly independent folk, rarely compliant to outside forces and pressures. Kangxi's decision in 1715 to place the young boy many believed to be the true reincarnation of the Sixth Dalai Lama under Qing protective custody in Xining, and then deploy troops along the Darzêdo-Lhasa route in Kham, compromised Lhasa's influence in Kham, but it probably had little impact on the majority of the people in Kham who did not live along the Darzêdo-Lhasa route. ${ }^{11}$

This changed in 1717 with the Zunghar occupation of Lhasa and the death of Lazang Khan, the expulsion of the Khoshot Mongols out of Central Tibet to Amdo and Kham, and the ongoing controversy surrounding the reincarnated spirit of the Sixth Dalai Lama. ${ }^{12}$ Qing control of the Darzêdo-Lhasa route in Kham was seen as critical in preventing the Zunghars and their allies from advancing further east to threaten Qing China. In the following year a Manchu garrison was established in Chengdu, the first of its kind along China's southwestern frontier, and in early 1719 the governor-general of Sichuan, Nian Gengyao (d. 1726), ordered Yue Zhongqi (1686-1754) to lead a reconnaissance force into Kham to bolster a small outpost at Bathang. To increase his odds of making it

\footnotetext{
10 Dirks, The Scandal of Empire, 335.

11 KXSL, 176:7a-b, 201:26a-b, 202:10a-11a, 203:8a, 210:8a; Dai, The Sichuan Frontier, 50-56; Ceng Xianjiang, "Huxi minzu yu Zang Yi zoulang" (A historical investigation of the nomadic peoples of the Tibetan-Yi corridor), 110-13.

12 Petech, China and Tibet, 15-24, Dai, The Sichuan Frontier, 76-83; Perdue, China Marches West, $227-32$.
} 
to Bathang, Yue was given permission to confer tusi titles upon influential local leaders who swore an oath of allegiance to the Qing throne. ${ }^{13}$

The most important feature of this tusi title was the patent (gaochi). It listed the name of the individual upon whom the hereditary tusi title was bestowed, the title and rank of the tusi post, a description of the geopolitical location of the tusi domain, the number of households within the tusi domain, and the annual tax demanded by the Qing state. More often than not, the patent indicated the Qing state's commitment to provide the tusi with political and military support, and preferential access to Chinese merchants and lucrative Chinese markets. So that Qing support for the tusi was clear, the written script used by the tusi, if one existed, was to be engraved next to the Chinese characters on the imperial patent. ${ }^{14}$ In addition, the Qing-issued tally $(f u)$ instructed the tusi to carry out a specific task, like patrol a portion of the Darzêdo-Lhasa route, and he could use the tally and seal (yinzhang) to requisition men and material to carry out this task. The patent and tally also authorized the tusi to lead a tribute mission to the Qing capital once every three years, though he was usually directed to present tribute to officials in the nearest provincial capital. In short, when an indigenous leader accepted Qing tusi status, he not only became a subject of the Qing emperor, and by extension an official of the Qing state, but also a critical instrument in the Qing empire-building process.

As Yue Zhongqi noted, history had shown how the Ming state used the tusi office at the end of the fourteenth century to increase its influence among the non-Han Chinese peoples in the southwestern frontier, and now at the beginning of the eighteenth century this vast area, consisting of the provinces of Yunnan and Guizhou, was an unquestioned part of China. More recently, in 1702 fortynine tusi titles were bestowed upon local leaders living near the border town of Darzêdo, and Yue now claimed in 1719 that every one of these forty-nine tusi had turned undeniably toward Qing China. ${ }^{15}$ Yue knew that even if he met resistance along the Darzêdo-Lhasa route he could entice the less powerful and marginalized communities to submit in order to acquire the status and protection the Qing state offered. The tusi office was a powerful weapon and Yue used it to his advantage. After he reached Bathang Yue reported that a multitude of

$13 K X S L, 273: 23 a-b, 277: 4 a-b, 279: 7 a-8 b, 280: 12 b-13 b, 283: 17 a-18 a, 284: 19 a-20 a ; S C T Z, 13: 2 a-3 b$, 95:6a-7b; QSLZ, 17:1249-56. From 1718 to 1721 Nian Gengyao was the governor-general of Sichuan. From 1721 to 1725 he was the governor-general of Sichuan and Shaanxi.

14 Tusi titles and ranks varied depending on the geographic and demographic size of the indigenous leader's domain. She Yize, Zhongguo tusi zhidu (China's tusi institution), 21-23; Gong Yin, Zhongguo tusi zhidu (China's tusi insitution), 68-71.

15 SCTZ, 97:33a-41b; Ceng Xianjiang, "Huxi minzu yu Zang," 109-111. 
tusi officials now lined the route between Darzêdo and Bathang, and that Qing troops could now travel from Darzêdo to Bathang without concern. ${ }^{16}$

When the Qing launched its two-pronged campaign on Zunghar-controlled Lhasa in 1720, Nian supervised the Sichuan assault force that marched along the Darzêdo-Lhasa route, aided in large measure by the tusi Yue had anointed months earlier. Kangxi's fourteenth son, Yinti (1688-1753), commanded the Qing force that departed Xining for Lhasa. ${ }^{17}$ The Sichuan force reached Lhasa a few weeks before Yinti's army, and the speed in which it reached Lhasa so impressed Kangxi that he ordered Qing forces to return to China by way of the Darzêdo-Lhasa route. In the wake of this withdrawal from Lhasa, Nian recommended sixty-six transport stations be established along the route and that tusi be appointed to manage each station. Nian intimated that Qing forces might need to return to Lhasa at a later date, and these tusi-controlled stations in Kham would guarantee a modest Qing presence in Kham. Kangxi agreed. Almost immediately a vigorous debate ensued as to which province, Sichuan or Yunnan, should assume jurisdictional authority over the towns of Darzêdo, Lithang, and Bathang, a clear indication the Qing was determined to preserve its presence in Kham. ${ }^{18}$

Nian waited only three months after Kangxi's death in December 1722 to submit his recommendation to annex Kham from Tibetan control. Nian's new sovereign, Yongzheng, was quite familiar with Nian's record of service in Sichuan, and his rescript to Nian's memorial admits to being intrigued by this proposal, but Yongzheng cautioned Nian that the time was not right for such a bold plan. Yongzheng agreed with Nian's recommendation that tusi remain in charge of the sixty-six stations and that Qing military outposts be permanently established in the major towns of Chamdo, Bathang, Lithang, and Darzêdo. Moreover, these Qing outposts and tusi officials, Nian urged, should assume control over the Tibetan postal service, a proposal Yongzheng did not object to.

Nian noted that Kham was rife with warfare, and its centuries-old reputation for banditry and violence was well deserved. Nian recalled Ming policy toward Yunnan and Guizhou as a cautionary lesson: "Bringing civilian rule to Dian (Yunnan) and Qian (Guizhou) consumed the energies of Ming officials from beginning [of the dynasty] to end [of the dynasty]." 19 Unlike what confronted the Ming in the southwest, there were no powerful autonomous kingdoms in Kham, and the notion of centralized Tibetan rule emanating from Lhasa had all but evaporated following the Zunghar occupation of Lhasa in 1717. Except

KXSL, 279:7a-8b, 280:12b-13b, 281:19b-20a, 283:17a-18a, 284:19a-20a; GZDZZ, 1288.3, 1288.5.

KXSL, 282:10b-11a; 284:19a-20a, 285:14b-15a; Petech, China and Tibet, 38-55.

18 KSXL, 287:14a-b, 19a-20b, 289:13b-20b; SCTZ, 192:9b-14b; Ceng Xianjiang, "Huxi minzu yu Zang," $118-21$.

19 GZDZZ, 1290.5. 


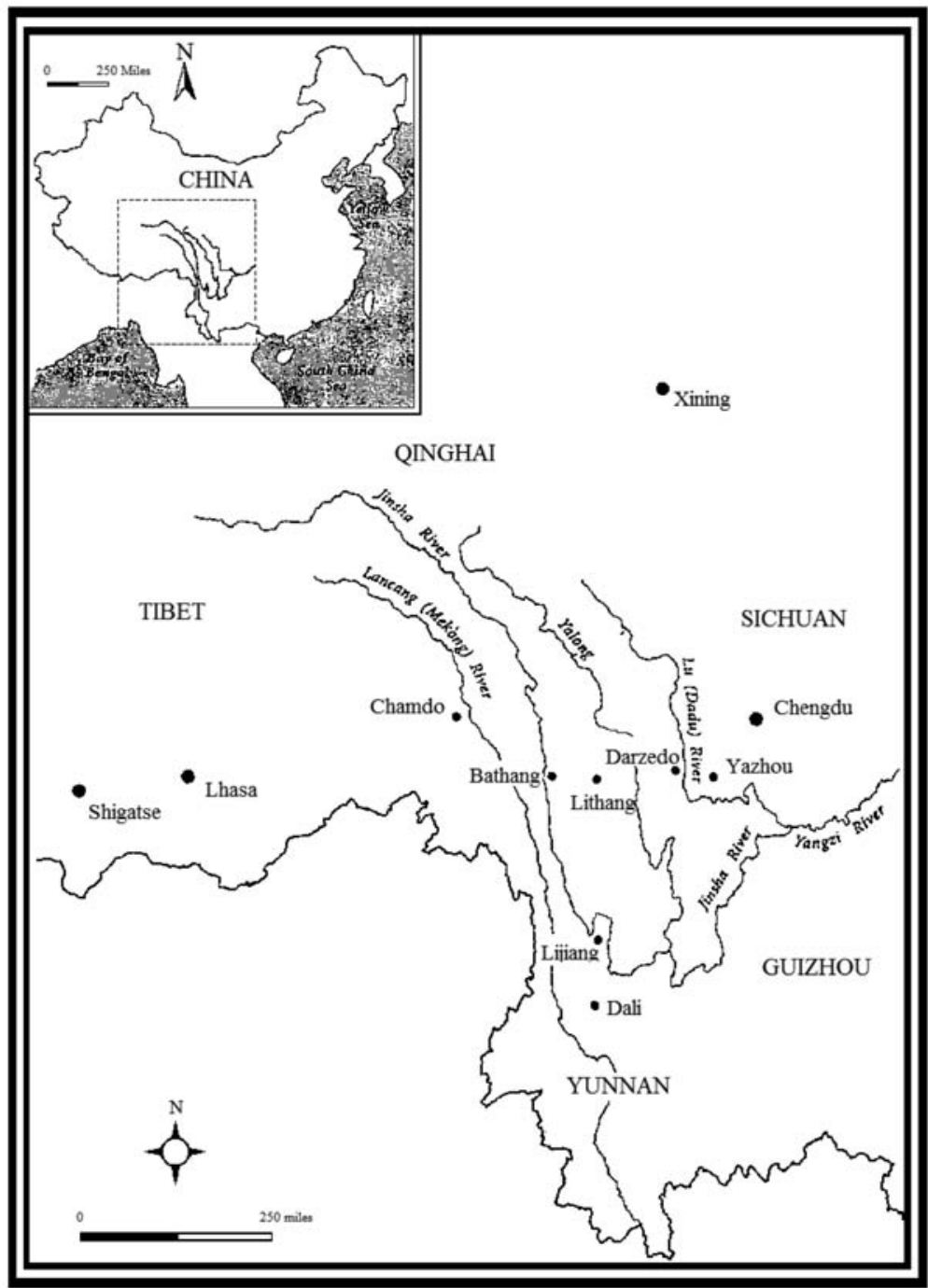

Amdo-Kham Prior to 1715 
for several large lamaseries, Kham was littered with small political entities, many of which were intensely hostile to one another. Nian believed the reward of tusi status could be used to manipulate local rivalries, punish recalcitrant local leaders, and ultimately assert Qing control over the people and territory of Kham. In recalling an earlier conversation he had had with Yue, Nian remarked, "several minor tusi offices are much easier to control than two or three large and powerful tusi, so it is to our advantage to confer tusi titles upon as many [local leaders] as possible, regardless of their power." ${ }^{20}$

In all likelihood Yongzheng discussed Nian's memorial with his advisors before ordering the withdrawal of the Manchu garrison from Lhasa in April 1723, a decision unpopular with Nian, Yue, and many other Qing military commanders in the western theatre. Yongzheng knew all too well, however, that his father's military campaigns into Tibet and Central Eurasia had been very expensive, and to continue such military operations would require far more revenue than was at hand. The emperor repeatedly mentioned that the cost of maintaining a Qing garrison in Lhasa weighed heavily on him, and this was one of the reasons given for closing the garrison in Lhasa. As Perdue indicates, this decision to withdraw the Qing garrison from Lhasa was part of an unprecedented "program of domestic austerity and institutional reform" implemented throughout China. ${ }^{21}$

This decision did not undermine Nian's plan for Kham, since the emperor redeployed 1,000 troops from the Lhasa garrison to a new outpost in Chamdo. Even though this outpost in Chamdo seemed in doubt four weeks later when Yongzheng abruptly withdrew all Qing forces to points east of Lithang, the emperor was not backing away from the general thrust of Nian's memorial, which was to confer tusi status upon indigenous leaders in Kham. He said as much in one of his remarks interspersed among the lines of Nian's memorial: "With support from tusi our military units can maintain a presence in this area." 22 Nevertheless, several officials stationed in the western frontier felt compelled by this sudden and unexpected retreat from Lhasa to voice their concern about Yongzheng's new approach toward Tibet and Kham. Yue Zhongqi, one of the more respected officials in this theatre, sent a number of memorials to the capital that contained transcribed appeals from local leaders imploring the throne to maintain a military presence in Kham. ${ }^{23}$

For example, in one memorial Yue included an appeal from a local leader from the Derge area of Kham named Danbaze. Danbaze's plea dispensed with

GZDZZ, 1290.5; SCTZ, 153:5a-b.

Perdue, China Marches West, 241.

GZDZZ, 1290.5. See also, YZSL, 5:2b-5a; GZDYZZZ, 1:105-06.

GZDZZ, 1291.5, 1293.1, 1293.11, 1345.1; YZSL, 3:31b-32a, 3:49a-50b, 5:2b-5a. 
the usual formality one sees in Qing memorials and cautioned Yongzheng that a withdrawal of Qing forces from Kham would embolden the Khoshot Mongols, who felt betrayed by the Qing, to attack those in Amdo and Kham who sided with the Qing. Khoshot Mongols from Kokonor had recently sent reconnaissance patrols into Derge territory, and Danbaze warned they were plotting to attack the western half of Kham, from Chamdo and Derge in the north to Bathang and Lithang in the south. Moreover, Danbaze noted that many of the lamaseries in Kham were sympathetic to the Khoshot's anti-Qing message and were mobilizing their substantial resources to aid the Khoshots. A withdrawal of Qing forces from Derge, Danbaze warned, would end badly for those indigenous leaders like himself who were subjects of the Qing emperor. Instead of jeopardizing the long-term stability of Kham by withdrawing Qing forces from the region, Danbaze recommended that the Qing bestow even more tusi titles upon indigenous leaders. ${ }^{24}$

Ever since 1640, when the Khoshot leader Gusri Khan (1582-1655) answered the Fifth Dalai Lama's request for military assistance, the Khoshot had enjoyed the unique position as protector of the Holy See in Lhasa and upholders of the Buddhist faith in Tibet. In 1717 the Khoshots were unable to protect Lhasa from the Zunghars, yet they still wielded considerable influence in central and eastern Tibet, as evidenced by Kangxi's request in 1720 for Khoshot assistance in the Qing campaign to Lhasa. From information available to us now it is clear Danbaze was referring to the expanding influence of Lobzang Danjin, grandson of Gusri Khan and leader of the Khoshots. Historians have long debated whether or not Lobzang Danjin instigated an anti-Qing revolt in 1723, noting that Lobzang Danjin and the Khoshots were never formally allied with the Qing and still operated autonomous of Qing influence in Kokonor. However, it is clear from Danbaze's account that monasteries in Kham were reacting favorably to the Khoshot's anti-Qing message, and that Qing influence in Kham was under assault. It is entirely plausible that the information Yongzheng received from his field commanders in Sichuan and Kham at this time convinced him to strike against Lobzang Danjin and the Khoshots in Kokonor. To do so would eliminate the Khoshot threat in the region and extend Qing influence into the Kokonor region, and it would undermine the anti-Qing elements in northern Kham. ${ }^{25}$

Thus, shortly after receiving Danbaze's report Yongzheng ordered Yue Zhongqi to lead 2,000 troops north from Darzêdo to Derge, where Danbaze

\footnotetext{
GZDZZ, 1291.5; GZDYZZZ, 2:343-44.

GZDZZ, 1292.1, 1293.10; Satō, "Lobzan Danjin no hanlan ni tsuite" (On Lobzan Danjin's revolt), 383-423; Kato, "Lobzang Danjin's Rebellion of 1723: With a Focus on the Eve of the Rebellion," 57-80; Ceng Xianjiang, "Huxi minzu yu Zang," 126-131.
} 
was located, to confront the Khoshots. Moreover, Yunnan Provincial Military Commander He Yulin was directed to position 1,000 men between the towns of Bathang and Chamdo on the Darzêdo-Lhasa route to provide logistical support for Yue's assault. Both Yue and He were authorized to demand that all indigenous leaders they encountered in their respective operations pledge allegiance to the Qing throne. Those who did were granted a tusi title and a promise of immediate financial and military support; those who did not were to be threatened with immediate elimination. By spring 1724 Qing forces had crushed Lobzang Danjin's revolt, and following Yue's famous campaign into the Chadamu Valley to put down another revolt by Tibetans and Khoshots, the Kokonor region (present-day Qinghai and Gansu) was incorporated into the Qing Empire. ${ }^{26}$

In his last significant contribution to Qing frontier policy, Nian submitted a lengthy memorial in June 1724 outlining his recommendations for the reconstruction of the Kokonor and Kham regions. With respect to Kham, Nian proposed an ambitious military-civilian colonization program. Qing forces stationed along the Darzêdo-Lhasa route were to be increased substantially. Nian wanted 2,000 troops stationed near Darzêdo, 500 soldiers near where the Yalong River and the highway intersect, 1,200 troops stationed in Lithang, 500 soldiers in the Cluo area between Lithang and Bathang where the indigenous population had been particularly defiant of Qing overtures, and 500 soldiers in Bathang. To support this large military footprint, Nian wanted the families of the Qing soldiers to relocate permanently to Kham to reclaim land (kaiken) and provide for the troops. He also proposed that criminals from Shanxi, Shaanxi, Shandong, Zhili, and Henan be sent to Kham to reclaim land for the military colonies. ${ }^{27}$

Next, Qing commanders should continue the policy of granting tusi titles to win over as many indigenous leaders as possible. Nian's plan focused not on granting tusi status to a few powerful leaders, which had been the trend up to this point in time; instead, he advocated granting minor-level tusi titles to a large number of indigenous leaders as the best way to ensure no one indigenous leader could organize a large following to challenge Qing control. "Kham should be littered with tusi who are wary of one another but dependent upon [us]." Moreover, "by bestowing tusi offices to local leaders, we will awe (wei) the people with our magnanimity and extend our influence into this troubled region without much sacrifice on our part." ${ }^{28}$ The tusi title was the instrument to induce individual local leaders to "turn to China," and for this reason Nian wanted Qing to aggressively expand the scope of the tusi program.

GZDZZ, 1292.1, 1293.6, 1293.10; YZSL, 12:2a-5a, 20:26b-29a; Perdue, China Marches West, 243-47. YZSL, 20:33b-35b; SCTZ, 13:11a-12a, 192:9b-14b; Feng Erkang, Yongzheng zhuan, 323-26.

YZSL, 20:27a. 
In what was certainly his most controversial recommendation, Nian argued for strict limitations on the size and activities of all lamaseries in Kham. $\mathrm{He}$ noted it was in the lamaseries that one could find a palpable anti-Qing sentiment. Lamaseries owned the best land, they had the most livestock, they had the largest concentration of people, and they were the least susceptible to the enticement of the tusi title. Specifically, Nian wanted each lamasery to sign an agreement with the Qing state stipulating that no more than 300 lamas could reside in a lamasery at any one time, and that Qing officials be allowed to conduct biannual inspections of each lamasery. All grain harvested on lamasery property should be turned over to Qing officials, and the state should assume responsibility for providing grain to each lamasery. Furthermore, lamaseries should be denied the right to tax the local population living near lamasery lands, because taxation was the sole right of the Qing government. Nian noted, "If the lamasery refused to agree to these terms, it should be destroyed." ${ }^{29}$ With these measures in place, "it is only a matter of time before this region is firmly under [Qing] control."

In May 1725, Nian Gengyao was transferred to Hangzhou and the post of Governor-General of Shaanxi and Sichuan was assigned to Yue Zhongqi, but Qing policy toward Kham did not fundamentally change. A few months later Yue submitted his own plan for Kham, a plan that owed much to Nian's original 1724 blueprint. The time was right, Yue believed, for the emperor to notify the Dalai Lama of the Qing emperor's intention to take possession of Kham. The current tusi in Kham had, for the most part, proven themselves trustworthy subjects of the Qing, and now military commanders stationed throughout Kham reported that minor tribal leaders were flocking to Qing outposts requesting tusi status. "The people [of Kham]," Yue wrote, "were turning [to Qing rule], so it was only appropriate to extend the emperor's grace to these new subjects." 11 Yue recommended three trusted officials, Oci, Bandi, and Zhou Ying, be permitted to lead a survey team to the extreme western edge of historic Kham to determine the new Qing boundary with Tibet. The normally demonstrative emperor simply wrote, "Noted" (zhidao liao) at the end of Yue's memorial and ordered the memorial sent to the Deliberative Council for discussion. The Deliberative Council agreed with Yue's proposal and recommended an edict be sent immediately to the Dalai Lama informing him of Beijing's decision to take possession of Kham. ${ }^{32}$

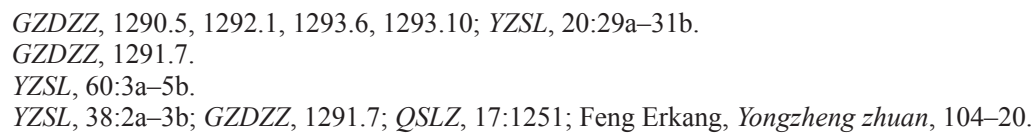


If the Dalai Lama entertained thoughts of once again asserting control over Kham, the arrival of Yongzheng's edict most certainly dashed any such hopes. The Dalai Lama also learned that Yongzheng had decided to curtail the influence of the Nyingma sect in Kham. Qing field commanders had waged a number of battles against Nyingma lamaseries, and Yongzheng was determined to eradicate the sect's ability to support anti-Qing activities in Kham. The Qing seizure of Tibetan land and the persecution of the Nyingma sect within Kham were acts opposed in Lhasa. Even pro-Qing ministers in Lhasa objected to Yongzheng's decrees. But before any organized resistance to Qing plans for Kham could develop, opponents of Beijing's erstwhile supporters gathered in Lhasa and murdered Kancennas on August 5, 1727. ${ }^{33}$ The repercussion of Kancennas's murder was Tibet's irrevocable slide into another prolonged period of instability.

Yongzheng's earlier decision to withdraw the Manchu garrison from Lhasa placed even more responsibility on his officials in Kham and Kokonor to provide information on the events taking place in Lhasa. Yue Zhongqi immediately requested permission to send Qing forces to Lhasa, but Yongzheng responded by cautioning that even though the situation in Lhasa looked serious, it would be prudent to first station a small, highly mobile reaction force in Chamdo (stationing troops in Chamdo was part of the original plan in 1721 but Yongzheng abandoned this plan shortly thereafter). Yue could then dispatch patrols from Chamdo into Central Tibet to gather additional information about Lhasa. "If the situation warrants," Yongzheng added, "we can then launch a full-scale assault on Lhasa, but we need to make sure our information is accurate before taking such action." 34 Yongzheng then concluded his rescript to Yue's memorial by ordering Yue and Acting Governor-General of Yunnan and Guizhou, Ortai (1685-1745), to deploy Qing forces from Yunnan and Guizhou along the Darzêdo-Lhasa route.

Evidently the August 1727 events in Lhasa convinced Qing officials not only to increase Qing troop strength throughout Kham in anticipation of another attack on Lhasa, but also to announce the creation of a new border separating Qing China and Tibet. Stone pillars marked the new border that ran roughly along a north-south axis through Bathang north toward Derge, closely approximating the traditional Tibetan division separating Central and Eastern Tibet (Kham). ${ }^{35}$ Yue and Ortai immediately praised the emperor's decisiveness in creating the new boundary and claimed the decision would bring lasting peace to this troubled

33 GZDZZ, 1291.3, 1293.1, 1293.6; 1293.10; Petech, China and Tibet, 108-15. Kancennas (Ch. Kangjinai) had mobilized Tibetan guerrilla forces to resist the Zunghar occupation of Tibet, and following the arrival of Qing forces in 1720 he was considered an ally of Beijing. Perdue, China Marches West, 236-7, 249.

34 GZDZZ, 1293.1.

35 GZDZZ, 1293.1, 1293.6; 1293.10; QSLZ, 17:1251; YZSL, 38:2a-3b; SCTZ, 191:1b-2a; DYLZ, 589. 


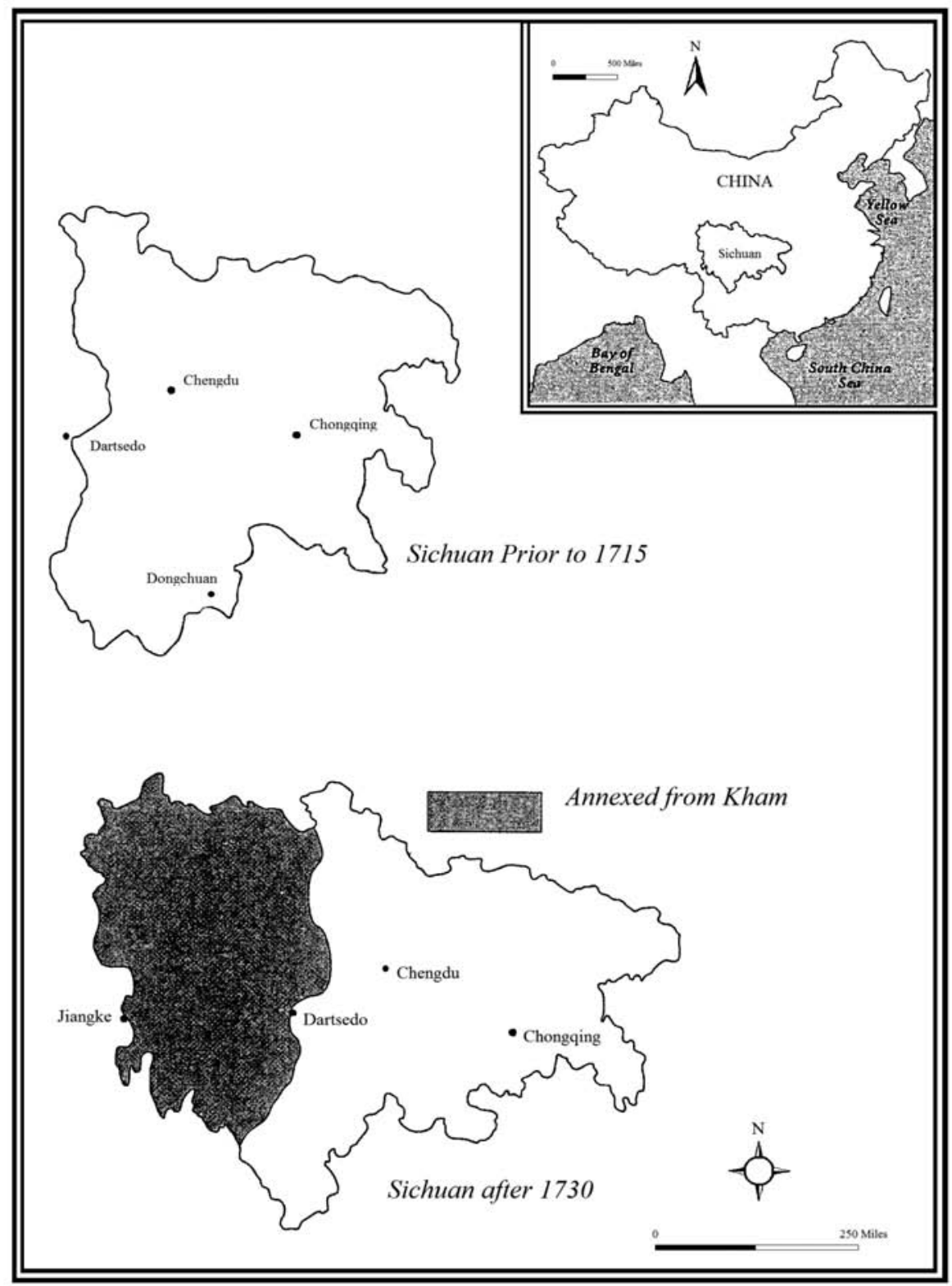

Sichuan Before and After the Annexation of Kham 
region. Unlike the situation in 1696 when Qing and Tibetan officials cooperated to establish the boundary separating Tibet and China near Darzêdo, Lhasa was not consulted on the creation of this new boundary.

Beijing moved quickly to incorporate Kham into Sichuan province by making it a part of Yazhou prefecture, however few Chinese volunteered to reside in the former Kham territory. Military colonists and military units were deployed in the region, and Chinese merchants from Sichuan and Yunnan took advantage of the Qing military presence to resume trade links between China and Tibet, but for the most part these people were not permanent residents. Moreover, Chinese civilian officials appointed to Yazhou rarely travelled west to Darzêdo, and even fewer dared venture into the former Kham region. Qing military officials and tusi governed Kham, and Beijing continued to encourage its officials to bestow tusi titles upon sympathetic local leaders. In 1728 the Qing extended formal recognition to fifty-four tusi in Kham, many of whom were classified as high-ranking tusi with the right to bestow minor tusi titles, like tumu (tribal leader), to subordinates; thus, the total number of tusi officials in Kham at this time was considerably more than fifty-four. This practice of allowing high-ranking tusi to grant minor tusi titles continued throughout the Yongzheng and Qianlong reigns. One source estimates that by the beginning of the nineteenth century there were approximately 350 tusi officials in the Kham area of Yazhou Prefecture. ${ }^{36}$

In 1715 the Zunghar Mongol assault on the oasis town of Hami signaled an escalation in the growing conflict over control of Tibet. Since 1705 the Khoshot Mongol leader Lazang Khan had relied increasingly on Qing support to impose Khoshot rule in Lhasa, much to the dismay of the Zunghars. In 1717 the Zunghars attacked Lhasa and drove the Khoshots out of Central Tibet, with many settling in the Amdo-Kham regions of Eastern Tibet. Kangxi responded by mobilizing Qing forces along China's entire western frontier and by preparing for the eventual 1720 invasion of Tibet that would dislodge the Zunghars from Lhasa. The Zunghars were not defeated in 1720 nor were their allies in Tibet entirely eliminated; they remained to be dealt with at a later date.

In anticipation of its 1720 campaign on Lhasa, representatives of the Qing state recognized the need to secure multiple transportation routes between China and Tibet. The quickest route, though not necessarily the safest route in 1717 was the Darzêdo-Lhasa route that ran west from the Tibetan-Chinese border town of Darzêdo through the Kham region of Eastern Tibet toward Lhasa. Kangxi immediately authorized his officials in Sichuan to bestow tusi

$36 \quad S C T Z, 191: 7 b$. 
titles upon Kham's indigenous elite in order to extend Qing influence into this region. The economic and military strength of Qing China overshadowed its rivals in the region, and this strength allowed it to convince many of Kham's indigenous leaders to accept the terms associated with the tusi title. Within ten years Beijing announced its annexation of Kham with a boundary that merged the region with Sichuan province, and Yongzheng launched a policy designed to alter the political, economic, and religious life in Kham. By the end of 1728 Qing forces were in firm control of Lhasa, and they had escorted the Dalai Lama back to his birthplace in Kham (Lithang), where he remained for the next six years under Qing “protective custody." With Lhasa and Kham under Qing control, in 1729 Yongzheng began financial and military preparations for an ambitious campaign against the Zunghar empire, a campaign that would take several decades and another emperor to complete.

\section{Copper and the Elimination of Tusi in Yunnan}

As Qing officials bestowed tusi titles upon Kham's indigenous leaders to gain a foothold in Tibetan territory, many of these same officials were equally aggressive in eliminating existing tusi offices in Yunnan in order to centralize civilian control over this internal frontier. The vast majority of tusi in Yunnan traced their hereditary status back to the last decades of the fourteenth century, when the Ming state established tusi offices in order to extend its influence into this frontier region, using methods similar those used by the Qing state in Kham. ${ }^{37}$ In 1715 only a fraction of the approximately 1,600 tusi offices established during the Ming remained. Many were eliminated during the sixteenth century as Han Chinese settlers colonized the region and civilian institutions replaced hereditary tusi offices, but following the end of Wu Sangui's rebellion in 1681 Kangxi demanded that his officials posted to the southwest follow a laissez-faire policy toward tusi, and he often publicly chastised officials who sought to curb tusi authority. ${ }^{38}$

Since the remaining tusi were located mostly in remote highlands far from Han Chinese settlements that now dominated the fertile lowlands, Qing officials had little difficulty obeying Kangxi's laissez-faire policy. In 1715, however, a large percentage of the copper and timber deposits Beijing now required to mint bronze coin were located in several of the more remote tusi jurisdictions. ${ }^{39}$

\footnotetext{
37 Throughout its 276-year history the Ming state conferred 1,608 tusi titles: 960 were military-rank tusi titles and 648 civilian-rank tusi titles. In Yunnan, Guizhou, and Sichuan alone, the Ming state bestowed 1,021 tusi titles, or 63 percent of all tusi titles issued during the Ming. Gong Yin, Zhongguo tusi zhidu, 57-63.

38 KXSL, 108:11b, 113:17a, 124:4b-5a, 124:16b-17b.

39 Vogel, "Copper Smelting and Fuel Consumption in Yunnan," 119-70; Yang Yuda, "Qingdai zhongqi (1726-1855) niandai Dian dongbei de tongye kaifa yu huanjing bianqian" (Development of the copper industry and environmental change in northeast Yunnan during the mid-Qing, 1726-1855), 165-74.
} 
As Qing officials sought to acquire these copper deposits, they quickly found themselves in conflict with Kangxi's laissez-faire policy and with tusi who jealously guarded their lands and natural resources.

Shortly after ascending the Qing throne in 1723, Yongzheng issued an edict in which he officially reversed his father's laissez-faire policy toward tusi in the southwest:

It has come to my attention that tusi in the southwest provinces fail to abide by our laws and regulations. These tusi often make excuses to tax and demand excessive labor service from the people under their control. Compared to the tax demands levied on our subjects, the indigenes (tumin) pay a much higher tax, even to the extent that their horses and cattle have been confiscated and their sons and daughters taken from their homes. They are literally at the mercy of their tusi. The indigenes are being butchered and they are angry, yet they dare not speak out against their tusi. ${ }^{40}$

Yongzheng argued that the tusi in the southwest acted this way in part because they had come under the influence of treacherous Han Chinese (Hanjian) - Han Chinese who Yongzheng described as having either committed crimes in China then escaped justice by fleeing to tusi-governed areas, or Han Chinese who simply refused to submit to Manchu rule. Yongzheng concluded his edict with a call for provincial officials to eliminate tusi who refused to abide by Chinese laws, failed to govern the people fairly and with compassion, and harbored treacherous Han Chinese. In effect, this imperial edict changed the negotiated agreement between the Chinese state and tusi in the southwest by demanding tusi accept Chinese law and Chinese cultural norms in governing their jurisdictions.

When Yongzheng appointed Ortai to the post of Governor-General of Yunnan and Guizhou late in the winter of 1725, he instructed Ortai to deal forcefully with recalcitrant tusi, and when possible replace tusi rule with direct Chinese civilian institutions, seize control of the region's valuable natural resources, such as copper, lead, salt, and timber, and streamline the provincial administrations of these two provinces to hold subordinate officials accountable for remitting taxes to provincial authorities. ${ }^{41}$ In 1725 , Yunnan's wealth in copper was well known to virtually everyone in Qing China. In the immediate aftermath of $\mathrm{Wu}$ Sangui's rebellion, Cai Yurong (1633-99) rapidly increased both copper and

\footnotetext{
$40 \quad$ YZSL, 20:17b-18a.

41 YZSL, 37:14a-b; Feng Erkang, Yongzheng zhuan, 333-42; Huang Pei, Autocracy at Work, 285-301; Smith, "Ch'ing Policy," 180-218; Giersch, Asian Borderlands, 43-62; Weinstein, Empire and Identity, $43-47$.
} 
salt production in Yunnan in order to offset costs associated with the Qing military occupation of the southwest. ${ }^{42}$ Cai had proven so successful in developing Yunnan's copper industry that in 1705 the Qing state moved to monopolize the market price of copper in Yunnan, not so much to use Yunnan's copper in China's mints but to effectively control this new source of wealth.

Investors who had flocked to Yunnan in the 1680s and 90s to open copper mines and smelting operations, however, now fled the region as the government's new policy to control the market price of copper undermined their ability to make a profit. By 1710 mines and mints in Yunnan were closing and copper production had declined from approximately 2 million jin a year in 1690 to less than half a million jin by $1715 .{ }^{43}$ Because copper production in Yunnan prior to 1715 was used almost exclusively to develop the regional economy of the southwest, this decline in production after 1705 had little effect on Beijing's two mints as they relied exclusively on shipments of Japanese copper to produce coin. Japan's decision in 1715 to limit copper exports to China compelled the Qing government to turn to the mines in Yunnan to meet its demand for copper.

Ortai prepared meticulously for this assignment. He was granted access to confidential reports written by current and former officials posted to the southwest, he interviewed officials who had been posted to the southwest, and most important, he had several meetings with Yongzheng, so he was clear as to what his sovereign expected. Ortai knew where the richest copper mines were located, Dongchuan prefecture, and he knew Dongchuan was a part of Sichuan, not Yunnan. Yet Dongchuan was physically much closer to Kunming, the capital of Yunnan and the location of Ortai's posting, than it was to Chengdu, the capital of Sichuan. ${ }^{44}$ Ever since Dongchuan had been added to the Qing realm as a hybrid civilian-tusi prefecture in 1698, it was Yunnan not Sichuan that responded to requests for political and military assistance, and Dongchuan's tusi visited markets in Yunnan and Guizhou, not Sichuan, to conduct trade. In fact, direct access from Chengdu to Dongchuan was difficult.

Situated between Chengdu and Dongchuan were two vast internal frontiers over which the Qing exerted very little control. To the northwest of Dongchuan, across the Jinsha River, was an area known as Liangshan (Cold Mountain), whose inhabitants the Chinese called Luoluo. The Liangshan Luoluo were related culturally to many of the tusi in Dongchuan, and were generally inhospitable

42 QSLZ, 7:435-40; Yunnan tongzhi, 29.4:11a-56a; Guy, Qing Governors, 331-34; KXSL, 106:18a-b.

43 Yan Zhongping, Qingdai Yunnan tongzheng kao (Study of copper administration in Yunnan during the Qing period), 6-8; Ueda, Shinchō shihai to kahei seisaku, 241-46; Qiu Pengsheng, "Shiba shiji Diantong shichangzhong de guanshang guanxi yu liyi guannian" (Notions of profit and the relations between state and merchant in the copper market of the 18th century), 70-71.

44 Dongchuan was approximately $400 \mathrm{li}$ from Kunming, but over 2,800 li from Chengdu. 
to outsiders. Historically, Han Chinese avoided travelling near this area. To the northeast of Dongchuan lay the large areas of Wumeng and Zhenxiong, and the peoples here were also related to the peoples in Dongchuan and Liangshan. ${ }^{45}$ Han Chinese were slightly more familiar with Wumeng and Zhenxiong, but only slightly. They knew the area to be heavily forested, sparsely populated, and rich in agricultural potential. To travel from Chengdu to Dongchuan, an official would avoid heading directly south into Liangshan, Wumeng, and Zhenxiong. Instead, he first entered Guizhou, travelled west along the Yunnan-Guizhou highway, and approached Dongchuan from the south. Ortai sought principally to extend Qing control over the vast internal frontier rich in copper, timber, and land where the three provinces of Sichuan, Yunnan, and Guizhou came together.

In March 1726, Ortai entered Yunnan travelling west from Guiyang toward Kunming along the Yunnan-Guizhou highway. He stopped in the small town of Malong, located directly south of Dongchuan. Much of the copper produced at the Tangdan factory, the most productive copper factory in Dongchuan, passed through Malong on its way to mints in Kunming. The officials in Malong reported that much of Dongchuan was still controlled by tusi, but Ortai already knew this. Two years earlier Ortai's predecessor, Gao Qizhuo (1676-1738), had lamented the fact that Han Chinese merchants and miners from Malong, Qujing, and Kunming had developed the Tangdan copper factory, but were continually harassed by tusi and tribal leaders (tumu) from Dongchuan and Wumeng. $\mathrm{He}$ observed: "It is truly a lawless area, and Sichuan seems either incapable or oblivious of the circumstances." "If Dongchuan became a part of Yunnan," Ortai noted shortly after his visit to Malong, "the aggrieved can expect redress, Yunnan troops will pacify the lawless Luoluo, and this savage wilderness will be transformed into fertile land from which people can reap the abundance." 47

Ortai was well aware the wealth of Dongchuan lay not in the fertile land itself, but in the minerals under the surface. The Tangdan factory had been in operation since the Ming period, but it was Cai Yurong's bold plan to develop the region's copper industry in the 1680s that greatly expanded copper mining. Even though the Qing government had decided in 1705 to monopolize the buying and selling of all copper in Yunnan, which resulted in an abrupt decline in copper production, Ortai was informed that the current exchange rate in Malong in 1726 was 1,400 coins per 1 tael of silver. This exchange rate was

45 Lin Yaohua, The Lolo of Liangshan; Fang Guoyu, Yizu shigao (Draft history of the Yi); Long Xianjun, Zhongguo Yizu tongshi gangyao (Draft history of the Yi nationality in China); Harrell, "The History of the Yi," 63-91.

46 YZZPYZ, 8:314-15; YZSL, 42:14a-b. Even before Ortai's arrival in the southwest, Gao Qizhuo had become very active in promoting the elimination of tusi offices in Yunnan and Guizhou.

47 YZZPYZ, 5:58. 
far from the ideal 1,000 coins per 1 tael of silver set by the Qing government, and it was this way because there was a plentiful supply of coin. In contrast, at the same time, many other parts of China reported a market price of 750 coins or less per 1 tael of silver. ${ }^{48}$ In other words, coin was plentiful in Yunnan, just not anywhere else. When Ortai departed Malong for Kunming, he knew that in order to restore vitality to the once vibrant copper industry in Dongchuan he had to bring not only Dongchuan under direct Qing control, but also the adjacent areas of Wumeng and Zhenxiong, areas still under tusi control. Once Wumeng and Zhenxiong were pacified, their timber stands could be exploited for use in the copper factories, their fertile lands could be reclaimed for agricultural production, and their roads used to transport copper north from Dongchuan to ports along the Jinsha River.

Ortai acted quickly. On April 26, one month after he visited Malong, Ortai requested permission to transfer Dongchuan Prefecture to Yunnan control, even though this request was made after he had dispatched troops to Tangdan on the pretext the factory workers required protection from "hostile barbarians." His message was clear: Yunnan was better positioned to protect these valuable copper mines than was Sichuan. Three weeks later on May 17, Yongzheng concurred. ${ }^{49}$ With Dongchuan now a part of Yunnan, Ortai turned his attention to attracting back to Dongchuan the investors who had fled the copper industry after 1705. According to Ortai,

it is common knowledge there are ample mineral resources here [Dongchuan]. Copper, gold, and silver, to name just a few, were exploited here during the Yuan and Ming [periods], but until now we [Qing] have refrained from developing these deposits. I propose we offer merchants from Sichuan, Yunnan, and Guizhou the opportunity to develop Dongchuan's resources. If merchants need capital to invest, we should provide the initial capital. If this region's resources are developed to their full potential, we will reap a financial reward ten-fold. ${ }^{50}$

With this announcement, miners, smelters, timber harvesters, transporters, and land-starved peasants began to flock to Dongchuan in search of work and wealth, and shortly thereafter these recent arrivals began to push north into tusi-controlled Wumeng and Zhenxiong. Tensions quickly escalated. It wasn't

YZZPYZ, 5:62; Ueda, Shinchō shihai to kahei seisaku, 121-29, 246-50.

YZZPYZ, 5:59-60; YZSL, 43:14b, 55:4a-5b; DYLZ, 581-82.

YZZPYZ, 5:60-61. 
so much the expansion of copper production that militarized the Dongchuan, Wumeng, and Zhenxiong region, although that certainly played a significant role; instead, it was the rapid expansion of Ortai's land reclamation (kaiken) program that aggravated the tusi and indigenes more than anything. Ortai knew the development of the copper industry could not proceed until local agricultural production was raised to a level sufficient to support the expansion in the mining population. Copper production and agricultural production went hand in hand, and his crash program of opening land to cultivation and large-scale in-migration of Han Chinese farmers formed part of his overall strategy to increase copper production. ${ }^{51}$

In its initial stage, Ortai's land reclamation program encouraged Qing officials and merchants to identify productive land neither taxed by the Qing state nor owned by Han Chinese, and then recommended they "contribute" to Yunnan's provincial treasury in exchange for the rights to sell the land to Han settlers. The recruitment of Han Chinese settlers was critical to Ortai's plan because he believed Han farmers were more capable at exploiting productive land than were non-Han, and more Han farmers residing in the area meant peace and stability in an increasingly Han Chinese environment. Furthermore, the revenue generated from "contributions" could be used as loans to Han settlers to help them purchase land from the "contributors" and bring it under cultivation. Once the land became productive, which Ortai estimated would take five years, title to the land would be issued to the Han settlers and they could begin paying taxes. Because such lands were often claimed by tusi, this reclamation program often resulted in hostilities between settlers and indigenes, and the region quickly became engulfed in violence. ${ }^{52}$

Unwilling to tolerate tusi resistance, Ortai put teeth behind Yongzheng's 1724 edict on tusi, the edict that reversed the Kangxi-era policy of accommodation toward tusi in the southwest. In one of his many memorials to Yongzheng, Ortai remarked on how the Ming established tusi to secure its presence in what was a hostile frontier. In time the Ming replaced tusi offices with civilian officials and the frontier became more accommodating to the Han. Today Yunnan and

51 YZZPYZ, 5:59-61, 89-91, 121-22, 156-58, 219-20, 383-86; Dongchuan fuzhi (Gazetteer of Dongchuan prefecture), 8:10b-20a; Smith, "Ch'ing Policy," $150-54$.

52 YZZPYZ, 5:89; YZSL, 59:26a-b, 60:10b-11b, 60:23b-24b, 96:20b-21a; DYLZ, 587-91; Chen Benming, Zhaotong Yizu shitan (Exploration of the history of the Yi in Zhaotong), 136-44; Yunnan tongzhi (Comprehensive gazetteer of Yunnan), 29.4:11a-56a; Guy, Qing Governors, 331-34; Yan Zhongping, Qingdai Yunnan tongzheng kao, 6. For more information on the "contribution system" (juanna zhidu) see, Xu Daling, Qingdai juanna zhidu (The Qing contribution system); Wu Yue, "Shindai ennō seidō ronkō," (Study of the office purchase system during the Qing dynasty), 103-30; Wei Caisha, "Qingchao juanjian zhidu jiqi yingxiang" (System of jiansheng degree purchasing and its influence during the Qing dynasty), 58-62; Kaske, "The Price of an Office," 281-308; Zhang, "Power for a Price." 
Guizhou are no longer hostile places, and most of the people living here are Han. Only in the remote highlands far from Han settlements can we find tusi. Tusi have outlived their usefulness, and it is only a matter of time before they completely disappear from the landscape..$^{53}$

Ortai saw the Ming precedent of eliminating tusi and establishing civilian rule as part of a long process of historical change, just as Nian Gengyao and Yue Zhongqi had noted in their memorials to Yongzheng. But where Nian and Yue saw tusi as an important initial instrument to extend Qing rule in Kham, Ortai viewed tusi in the southwest as an outdated legacy of Ming imperial expansion and an embarrassing impediment to civilian rule. In Yunnan and Guizhou, the Qing was completing what the Ming started.

Local officials in Yunnan and Guizhou immediately recognized the sudden change in policy and lined up to voice their support for Yongzheng's (and Ortai's) aggressive stance toward tusi in the southwest. Wang Yiren, the Guizhou provincial military commander, reiterated his belief that education was the best means to bring about the transformation of the indigenes: "Only through education can the Miao acquire the moral aptitude necessary to become members of a civilized society." 54 Yet Wang added that when tusi refuse to return to civilization (guihua), flagrantly break the "laws of the land," and cooperate with treacherous Han to appropriate tax revenue, then force must be used and they must be eliminated. In 1726 the acting governor of Guizhou, Shi Liha, echoed Wang's sentiments when he wrote, "tusi have outlived their usefulness in Qian [Guizhou], and the time has come for civilian officials to govern the entire province. Eliminating the remaining traces of tusi rule should be a priority, and officials should be given the authority to do so. The final phase [emphasis added] in bringing Qian into China proper should begin immediately." 55

Ortai relied on Yongzheng's unwavering support to execute this final phase and eliminate tusi, yet the scale of Ortai's actions in the southwest was modest in relation to the geographic size of Yunnan and Guizhou. In Yunnan only twenty-three tusi offices were eliminated during the Yongzheng reign(1723-35), and of this number fourteen tusi were abolished in the resource-rich areas of the Dongchuan, Wumeng, and Zhenxiong region. Of the remaining nine cases, six were carried out in the wealthy tea-producing areas of Zhenyuan and Puer in south-central Yunnan. During this same period, only nineteen tusi offices were eliminated in Guizhou, and most of these tusi were located in northwest Guizhou, adjacent to Zhenxiong, an area rich in zinc and timber. This did not

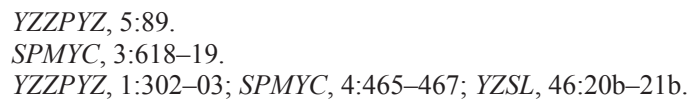




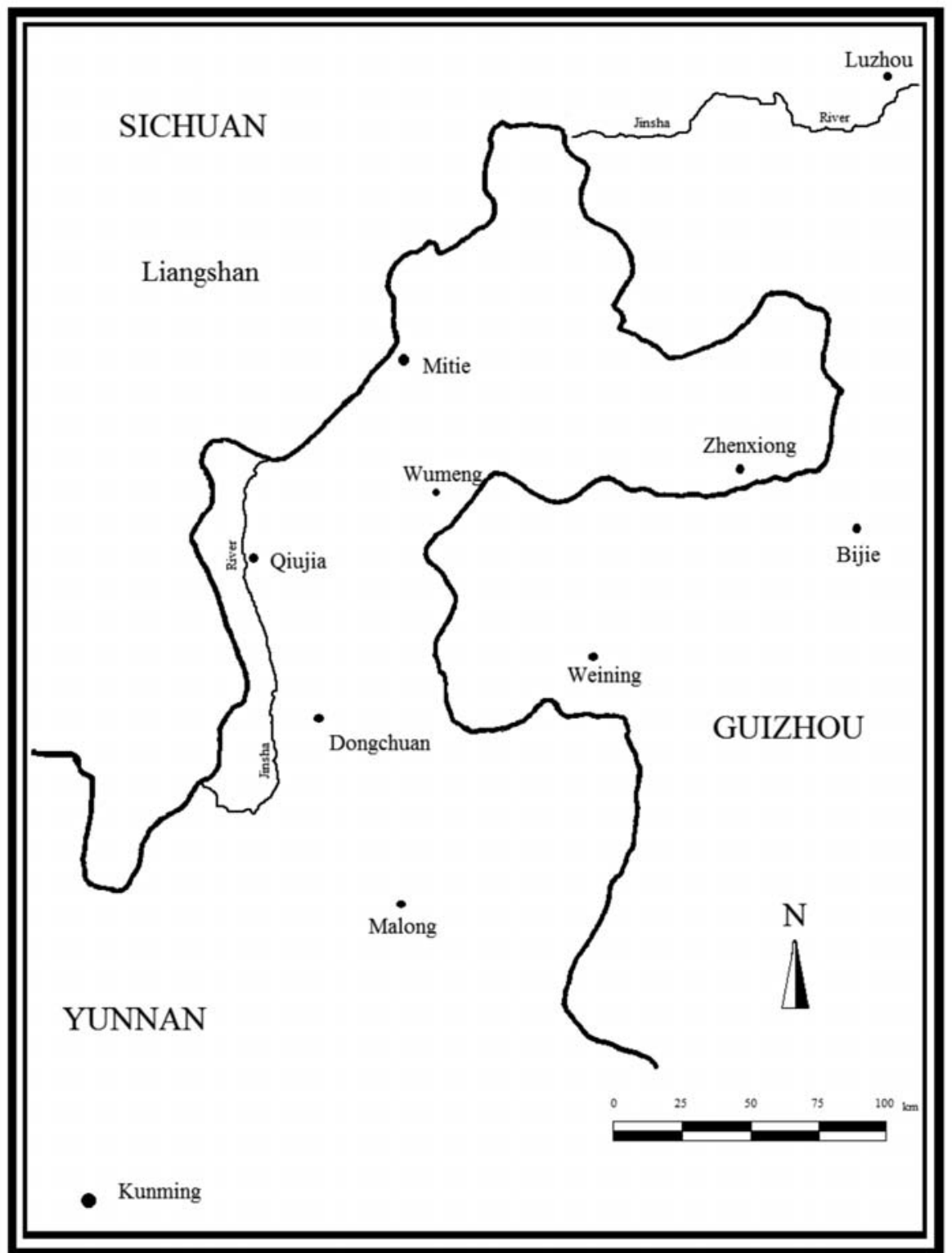

Northeast Yunnan, ca. 1730 
represent all of the remaining tusi in Guizhou, but it was close. The process of Ming imperial expansion in the southwest had nearly run its course. In virtually every instance the objective was to confiscate resource-rich territory controlled by tusi and recruit Han Chinese to either "reclaim" land or launch commercial enterprises to exploit the area's natural resources. ${ }^{56}$ With respect to Dongchuan, Wumeng, and Zhenxiong, the price paid by the indigenes to satisfy Beijing's demand for copper was exceedingly high.

In the same April 26, 1726, memorial in which Ortai requested Dongchuan be made a permanent part of Yunnan, he also informed Yongzheng that he had ordered the Dongchuan prefect, Huang Shijie, to dispatch scout units into southern Wumeng to assess the military capability of Lu Wanzhong, the fifteenyear-old tusi of Wumeng. Huang's troops were given two additional tasks: to meet with as many tribal leaders ( incentives to turn them against $\mathrm{Lu}$ Wanzhong, and to hunt down and capture $\mathrm{Lu}$ Dingkun, the tusi's charismatic uncle. Upon his brother's death, Lu Dingkun had tried unsuccessfully to seize the tusi title for himself, thinking his young nephew ill-prepared to manage the affairs of the tusi office. ${ }^{57}$ The indigenous elite (the Lu patriclan and various tribal leaders) in Wumeng, however, rallied to support Lu Wanzhong's claim to the tusi office, forcing Lu Dingkun and a band of approximately 2,000 warriors to flee south near the Dongchuan-Wumeng border, where they attacked Han settlers, rustled livestock, and kidnapped Han working in and near the copper mines of Tangdan. It was Lu Dingkun whom the people of Dongchuan feared most, and Ortai sensed this when he visited Malong a few weeks earlier. ${ }^{58}$

According to one of Huang's field reports, many of the tumu in Wumeng also lived in fear of Lu Dingkun, and they willingly agreed to assist Qing efforts to capture him. Aware that his safety in southern Wumeng was now threatened, Lu Dingkun attempted to flee across the Jinsha River into Liangshan, which he knew Qing forces would not dare enter. But before he could reach the Jinsha River he was intercepted by a militia force and convinced to first meet with Qing officials to see if a truce could be negotiated. When word reached Huang

\footnotetext{
56 Li Shiyu, "Luelun tusi zhidu yu gaitu guiliu" (A brief discussion of the native official [tusi] institution and bureaucratic consolidation), 273-301; Smith, "Ch'ing Policy," 155-173; Giersch, Asian Borderlands, 43-62; Weinstein, Empire and Identity, 43-57. By 1750 there were only fifty-three tusi in Guizhou, down from the estimated 128 tusi in Guizhou at the beginning of the Qing.

57 YZZPYZ, 5:98-100; YZSL, 42:14b, 55:15a-16a; Dongchuan fuzhi, 8:5b-14a; DYLZ, 582-83. According to Huang's report, the Wumeng tusi commanded a force no greater than 10,000 troops, half of whom were mounted cavalry. Their weapons were primitive, mostly swords and bows and arrows. They possessed a handful of firearms and only two cannon. YZZPYZ, 5:99.

58 According to a memorial by Yue Zhongqi, Lu Dingkun had committed over 30 crimes against the people of Dongchuan, and Lu Wanzhong had failed to stop him. YZZPYZ, 5:93; YZSL, 55:15a-16a.
} 
Shijie that Lu Dingkun was contemplating surrender, he hurriedly arranged to meet with Lu Dingkun, after which the two men "swore a blood oath of brotherhood." On the following day, Huang escorted Lu Dingkun and his two sons, Lu Wanfu and Lu Wangui, to Dongchuan, where they met with Liu Qiyuan, the Dongchuan regional commander (zongbing), and waited for Ortai's instructions. Impressed by Lu Dingkun's willingness to assist the Qing against his nephew in Wumeng, Liu Qiyuan appointed Lu assistant brigade commander (shoubei), and agreed to be the godfather to Lu's two sons. ${ }^{59}$

When notified of Lu Dingkun's presence in Dongchuan, Ortai, who was traveling between Guizhou and Yunnan, altered his itinerary to meet this Luoluo rebel in Dongchuan. Like Huang and Liu before him, Ortai was impressed by Lu's offer to assist the Qing to eliminate the Wumeng tusi; so much so that Ortai changed Lu Dingkun's appointment from assistant brigade commander to the hereditary post of native assistant brigade commander (tu shoubei). During their meeting, Lu Dingkun reported that the real authority in Wumeng was not the young tusi Lu Wanzhong, but an elderly Han Chinese man named Liu Jianlong. Liu had lived in Wumeng for many years and was a close advisor to $\mathrm{Lu}$ Wanzhong's recently deceased father, Lu Dingkun's brother. Liu had groomed the young Lu Wanzhong since birth, and now wielded considerable influence over both the tusi and his family. In fact, Lu Dingkun believed his nephew had already fled Wumeng to Zhenxiong, where he stayed as a guest of the tusi Long Qinghou, whose mother was Lu Wanzhong's aunt on his father's side. ${ }^{60}$

Ortai ordered Lu Dingkun to write a letter to Liu Jianlong to persuade him to surrender the Wumeng tusi seal to Ortai in Yunnan. Although we do not have $\mathrm{Lu}$ Dingkun's letter, we do have Liu Jianlong's reply, and in it Liu firmly rebuffs Lu Dingkun's request that he hand over Lu Wanzhong and the Wumeng tusi seal to Ortai in Yunnan. According to Liu Jianlong's reply,

Sanguan [Lu Dingkun] wrote to me asking that I persuade Lu Wanzhong to surrender to Dian [Yunnan], and that if he doesn't surrender it will in fact be my fault. All territories under heaven belong to the [Qing] emperor. To surrender to Sichuan or Yunnan, what's the difference? But Wumeng is part of Sichuan, and a few of the officials [in Wumeng] are from Sichuan. Moreover, the emperor has written an edict critical of Lu Dingkun. If I follow Lu Dingkun's words and tell $\mathrm{Lu}$ Wanzhong to send his seal to Yunnan, then I am promoting rebellion because I am agreeing to the demands of the emperor's

$59 \quad Y Z Z P Y Z, 5: 59-61 ; D Y L Z, 583-85$.

60 YZZPYZ, 5:59-61, 98-103. 
enemy, so I can't do this. I may be old and stubborn, but I dare not ask the tusi to rebel.... Sanguan [Lu Dingkun] does not possess any land to speak of and he is not attached to any area and office, so he can move as he sees fit. However, the young Saofu [Lu Wanzhong] has Sichuan's seal and as tusi he can't easily move to another province and set himself up in another official's territory.... On behalf of Saofu [Lu Wanzhong], I submitted a report to Sichuan's official [Yue Zhongqi] requesting that he abandon plans to eliminate the Wumeng tusi office. If, however, he [Yue Zhongqi] permits us to join Yunnan, then we will not hesitate for one minute to make the overnight journey to cross the river [Niulan River] ${ }^{61}$

According to Qing regulations tusi officials were prohibited from complying with such a request, and Liu Jianlong even goes so far as to scold Lu Dingkun for acting inappropriately. The Wumeng tusi was appointed by the Qing emperor, who turned over the management of day-to-day affairs to Sichuan authorities in Chengdu. Neither Lu Dingkun nor Ortai in Yunnan had the authority to dictate policy toward the Wumeng tusi. As Liu states clearly at the end of his reply, "if Sichuan officials inform us that we are to take orders from Yunnan, then we will take orders from Yunnan, but for now we take orders from Sichuan." 62 Unfortunately for Liu, he was not privy to the decisions made by Yongzheng, Ortai, and Yue Zhongqi regarding the future of the Wumeng tusi: this tusi office was to be eliminated and the area placed under Yunnan control.

Shortly after Liu Jianlong's reply reached Dongchuan, Liu Qiyuan led a contingent of troops across the Niulan River into Wumeng. As the squad ascended a narrow pass just north of the river, they were attacked. Liu and a handful of soldiers were able to make their way back across the river to safety, but an infuriated Ortai immediately ordered provincial forces from Yunnan and Guizhou to attack Wumeng and Zhenxiong from the south and east. The former rebel Lu Dingkun was given command of an irregular force made up mostly of his original warriors and ordered to attack Wumeng, which he did with a vengeance. Yongzheng also ordered Yue Zhongqi to deploy Sichuan forces to apprehend anyone attempting to flee into Sichuan. The only avenue of escape from this Qing encirclement was to cross the Jinsha River into Liangshan to the west, and many fled in this direction. ${ }^{63}$

Chen Benming, Zhaotong Yizu shitan, 138-39.

Chen Benming, Zhaotong Yizu shitan, 139.

Chen Benming, Zhaotong Yizu shitan, 138-41; YZZPYZ, 5:98-103; YZSL, 55:15a-16a, 59:26a-27a, 81:19b-20a; Dongchuan fuzhi, 6:12a-17b. 
When word reached Zhenxiong that Qing forces were mobilized to eliminate the Wumeng and Zhenxiong tusi, Lu Wanzhong left Zhenxiong for Sichuan in hopes of convincing Yue Zhongqi that neither he nor the Zhenxiong tusi Long Qinghou had done anything wrong. But his entourage was intercepted by Sichuan troops and escorted to Kunming. Shortly thereafter, Long Qinghou fled Zhenxiong for the nearest Qing brigade (ying) in Sichuan to surrender his office seal. He too was escorted to Kunming. As word spread that the Wumeng and Zhenxiong tusi were under arrest in Kunming, resistance began to wane and within three months approximately 200 tumu had been rounded up and sent to Kunming to await trial alongside their former tusi. ${ }^{64}$

In less than a year Ortai had convinced the Qing throne to transfer Dongchuan, Wumeng, and Zhenxiong from Sichuan to Yunnan control; he eliminated the two largest tusi in the region, Wumeng and Zhenxiong; he purged the region of lower-level members of the indigenous elite (tumu) who had been enfeoffed by the Wumeng and Zhenxiong tusi to govern specific areas within the tusi's jurisdiction; and most important, he secured Qing control over the vast copper deposits in Dongchuan and the immense timber stands and fertile land in Wumeng and Zhenxiong needed to exploit the copper ore. The Qing troops mobilized for the campaign against Wumeng and Zhenxiong were permanently deployed to a large fort in Wumeng and two smaller forts in Dongchuan and Zhenxiong. Nearly 4,000 troops from the Qing fort in Weining (Guizhou) alone were redeployed to Wumeng. Interspersed between these three forts was a vast network of smaller outposts situated along roads and mountain trails. Now that the two tusi officials and much of the local elite were either dead, in Kunming awaiting trial, or in Liangshan as refugees, these military units became not only permanent residents but a new landholding elite-local Qing commanders were charged to carry out land reclamation in their areas. ${ }^{65}$

The occupation of Dongchuan, Wumeng, and Zhenxiong, the land reclamation program and accompanying influx of Han Chinese settlers, the felling of vast timber stands to feed the copper factories in Dongchuan, and the impressment of indigenes to work in the copper mines reignited a new round of Luoluo resistance. At one point in November 1728, the situation became so dire that when a Sichuan field commander reported he had finally brought "peace" to northern Wumeng by massacring nearly a thousand rebels at the town of Mitie, Ortai became ill and bedridden in despair for three days ${ }^{66}$ Even Yongzheng

\footnotetext{
${ }^{64}$ YZZPYZ, 5:110-25. Long Qinghou was subsequently sent to internal exile in Jiangnan, whereas Liu Jianlong was executed in Kunming. DYLZ, 588.

65 YZZPYZ, 5:121-36; YZSL, 66:10a-12a, 72:22a-b; Chen Benming, Zhaotong Yizu shitan, 139-43.

66 YZZPYZ, 5:430-34; DYLZ, 598-90; QSLZ, 17:1425.
} 
expressed discomfort at reading reports of Qing soldiers purposely mutilating women and children in acts of revenge. The real shock occurred in October 1730 when Luoluo forces secretly surrounded the Qing fort at Wumeng and slaughtered its Han Chinese inhabitants, including the regional commander, Liu Qiyuan. When Ortai learned that Lu Dingkun's two sons had played a role in organizing Luoluo resistance against the Qing, he tendered his resignation. Yongzheng refused to accept Ortai's resignation request, but he did authorize Ortai to direct a punishing campaign throughout Wumeng and Zhenxiong. By the summer of 1731, Qing commanders reported that Wumeng and Zhenxiong were literally devoid of human life: the Luoluo who had massacred Qing soldiers and Han Chinese settlers in 1728 were now themselves "exterminated."

In the early months of 1732, Ortai reported Luoluo resistance in Wumeng and Zhenxiong had been crushed. Qing military units were once again ordered to settle the area as permanent residents, never to return to their native place, and civil and military officials were authorized to initiate another massive land reclamation program. Han Chinese settlers again flooded into the DongchuanWumeng region in search of land and employment. A few months later Ortai was recalled to Beijing, his work in the southwest complete, his work a success. In one shockingly candid moment during Ortai's tenure in the southwest, Yongzheng confided to Ortai: "When I can't trust myself, I can trust you."68 Why such praise for an official whose reputation was now tarnished by the brutal campaigns against the Luoluo? The answer can be summed up in one word: copper.

At the time of Ortai's appointment in 1725, the copper mines in Yunnan produced about 1 million jin annually, an amount barely sufficient to meet Yunnan's demands. In fact, the year before (1724) the governor of Zhejiang suggested Hunan and Hubei purchase copper from Yunnan to complete their quota obligations to the mints in Beijing, a request Yunnan was unable to accommodate. ${ }^{69}$ In 1727, just one year after Ortai assumed his post in Kunming, the mines and factories in Dongchuan alone produced over 4 million jin of copper, which allowed Yunnan to ship 1 million jin to Hunan and Hubei, and another 1 million jin to Jiangsu. The copper shipped to Hunan, Hubei, and Jiangsu eventually made its way to the mints in Beijing, the first time Yunnan copper was used to mint coin in the Beijing mints. ${ }^{70}$ In 1730, officials in Guangdong received

\footnotetext{
YZZPYZ, 5:427-34, 439-47; YZSL, 99:12a-13a, 99:16b-19a; DYLZ, 608-12; QSLZ, 13:1172-74, 15:1346-47; Smith, "Ch'ing Policy," 164-65; Chen Benming, Zhaotong Yizu shitan, 148.

68 YZZPYZ, vol. 5, 91.

69 Yan Zhongping, Qingdai Yunnan, 11; YZZPYZ, 5:169-70.

70 Yan Zhongping, Qingdai Yunnan, 11-12; Ueda, Shinchō shihai to kahei seisaku, 151-60; Pan Xiangming, "Qingdai Yunnan de kuangye kaifa" (Development of the mining industry in Yunnan during the Qing period), 333-63.
} 
permission to purchase Yunnan copper to supply its own provincial mints and to fulfill its quota obligations to the Beijing mints. When he departed Yunnan for Beijing in 1732, Ortai declared that Yunnan's mines and factories were producing nearly 8 million jin of copper a year, and much of this copper was transported out of Yunnan to the mints in Beijing. ${ }^{71}$ And in 1737, just 11 years after Ortai took up his post in Yunnan, his protégé and current governor-general of Yunnan and Guizhou, Yengišan (1696-1771), reported Yunnan could now satisfy all of China's demands for copper, and it did. ${ }^{72}$

Several scholars have examined this dramatic increase in copper production in Yunnan, with perhaps Yan Zhongping's 1957 study the most authoritative. In this study Yan analyzed statistical information covering 71 years, from 1740 to 1811, compiled by the Copper Bureau, the government office in Yunnan tasked with procuring copper from the mines and forwarding it to various mints outside of Yunnan, including the two mints in Beijing. According to Yan, during these 71 years Yunnan exported approximately 730,330,000 jin of copper, or roughly $10,140,000$ jin annually. ${ }^{73}$ Yan's data were in large measure confirmed in a 1983 study by Wei Qingyuan, who discovered a memorial written in Qianlong 35 (1771) in the First Historical Archives that detailed the amount of copper shipped from Yunnan from 1736 to 1770 . The 1771 memorial indicated slightly less copper was exported out of Yunnan than what Yan's Copper Bureau figures indicated, but the statistical variation between these two sources is quite small. ${ }^{74}$ A more recent article by Yang Yuda argues that both Yan and Wei underestimated the amount of copper produced in Yunnan because neither study accounted for private copper that remained in Yunnan. Many of the miners and factory managers were paid in copper, and they sold their copper at local markets in exchange for daily necessities. ${ }^{75}$ In any case, Hans Ulrich Vogel estimates that from the time of Ortai's arrival in Yunnan in 1726 to the middle of the nineteenth century, the copper produced in Yunnan's factories allowed the Qing state to mint over 330 million strings ( 1 string $=1,000$ coins), or 330 billion coins. ${ }^{76}$

\footnotetext{
71 Yan Zhongping, Qingdai Yunnan, 12-13; Ueda, Shinchō shihai to kahei seisaku, 177-84; Kawakatsu "Shin-Kenryūki Unnandō no kyōun mondai" (Copper transport from Yunnan to Beijing in the Qianlong period of the Qing dynasty), 526-38; Yang Yuda, “Qingdai zhongqi (1726-1855) niandai," 157-74.

72 Yunnan tongzhi, 76.8:15b-18a; Ueda, Shinchō shihai to kahei seisaku, 182-83; Yan Zhongping, Qingdai Yunnan, 13 .

73 Yan Zhongping, Qingdai Yunnan, 81-84.

74 Wei Qingyuan and Lu Su, "Qingdai qianqi kuangye zhengce de yanbian" (Development of mining policy during the early Qing period), 37-54; Yang Yuda, "Qingdai zhongqi," 164-67.

75 YZSL, 60:17b-20a. Based on Yang Yuda's estimates, by 1850 approximately twenty percent of the timber in the Dongchuan-Wumeng-Zhenxiong area had been harvested to support the copper industry. Yang attributes the severe soil erosion that now afflicts this region to the massive deforestation that occurred after the arrival of Ortai in 1725. Yang Yuda, "Qingdai zhongqi (1726-1855) niandai," 167-72.

76 Vogel, "Chinese Central Monetary policy, 1644-1800," 10.
} 


\section{Conclusion}

In 1715 Qing China was forced to respond to two separate international events, the emerging Zunghar Mongol threat in Central Eurasia and Japan's decision to restrict copper exports to China. Kangxi immediately mobilized Qing forces along China's western frontier, and following the Zunghars' invasion of Tibet two years later he utilized the military and economic superiority of China to confront the Zunghars. One aspect of the Qing response was the annexation of the Kham region of Eastern Tibet. Qing officials conferred tusi titles upon members of Kham's indigenous elite in order to forge a network of alliances that would eventually "turn" this region away from Lhasa and toward Beijing. In return the Kham elite swore an oath of loyalty to the Qing throne and agreed to act on behalf of Qing interests in Kham. The Khoshot Mongol presence in Amdo and Kham in the 1720s only accelerated the need to transform the Kham elite into allies of the Qing state. By the end of 1727, the multitude of tusi officials in Kham and the continued political instability in Lhasa afforded the Qing state the opportunity to unilaterally seize Kham from Tibet and fold it into China's Sichuan province.

Japan's restrictions on copper exports endangered China's long-term financial health because people depended on bronze coin for daily transactional needs. By 1723 copper shortages had become acute. Since large copper deposits existed on tusi lands in Yunnan, this dilemma folded neatly into the Zunghar strategic threat to southwest China: a policy of replacing tusi with Chinese civilian institutions would consolidate Qing control over a strategically vulnerable region and secure desperately needed copper for China's economy. Qing officials assigned to Sichuan and Yunnan were therefore tasked to implement simultaneously two ends of the empire-building process, the initial advance into foreign territory (Kham) through negotiated alliances (tusi), and closing the empire in Sichuan, Yunnan, and Guizhou with the elimination of tusi offices and the establishment of a unified civil administration.

The Qing desire to control the copper deposits in the southwest carried with it an added element that was not present in its policies toward Kham, the selfserving rhetoric of a civilizing empire. Unlike Kham, which was clearly foreign territory in 1715, the southwest had been an unquestioned part of China since at least the fourteenth century, if not before, and by the eighteenth century Han Chinese settlers had come to inhabit large parts of Yunnan and Guizhou. Nevertheless, the sizable non-Han population and the continued presence of tusi offices gave the impression of an unfinished empire, a region yet to be incorporated fully with China. Interestingly Yongzheng and his officials relied not on economic arguments to justify the seizure of indigene resources, but instead on culturalist 
claims that validated their actions in the name of imparting civilization to the indigenes. Chinese civilization was the weapon used to motivate Qing officials into believing their actions, however disconcerting, were necessary to lift the indigenes out of their crude, uncivilized existence. And finally historians who believed in the efficacy of Chinese civilization wrote (and still write) admiringly of well-intentioned officials struggling to impart the benefits of Chinese civilization to the non-Han in the southwest. This was the rhetoric of empire, and this rhetoric concealed Qing China's deliberate appropriation of land and resources in the southwest.

\section{Glossary}

\begin{tabular}{|c|c|c|c|}
\hline Baoquanju & 寶泉局 & Liu Qiyuan & 劉起元 \\
\hline Baoyuanju & 寶源局 & Lithang & 理塘 \\
\hline Bathang & 巴塘 & Long Qinghou & 隴慶候 \\
\hline Cai Yurong & 蔡毓榮 & Lu Dingkun & 祿鼎坤 \\
\hline Chamdo (Chamuduo) & 叉沐朵 & Lu Wanfu & 祿萬富 \\
\hline Chengdu & 成都 & Lu Wangui & 祿萬貴 \\
\hline Danbaze & 旦巴則 & Lu Wanzhong & 祿萬鍾 \\
\hline Darzêdo (Dajianlu) & 打箭爐 & Luoluo & 玀玀 \\
\hline Dian & 滇 & Malong & 馬龍 \\
\hline Dongchuan & 東川 & $\operatorname{man}$ & 蠻 \\
\hline gaitu guiliu & 改土歸流 & Miao & 苗 \\
\hline Gao Qizhuo & 高其卓 & Mitie & 米貼 \\
\hline gaochi & 誥敕 & $\mathrm{mu}$ & 畧 \\
\hline guandai & 冠帶 & neidi & 內地 \\
\hline Guizhou & 貴州 & Nian Gengyao & 年美堯 \\
\hline Hanjian & 漢奸 & Ortai & 鄂爾泰 \\
\hline Huang Ming & 黃明 & pai & 牌 \\
\hline Jin & 斤 & Puer & 普洱 \\
\hline Jinsha & 金沙 & Qian & 黔 \\
\hline juanna & 捐納 & Qujing & 曲靖 \\
\hline kaiken & 開墾 & Sanfan zhi luan & 三藩之亂 \\
\hline Kangding & 康定 & shanhou & 善後 \\
\hline Kunming & 昆明 & Shi Liha & 士庽哈 \\
\hline Liangshan & 涼山 & Songpan & 松潘 \\
\hline Liu Jianlong & 劉建隆 & Tangdan & 湯丹 \\
\hline
\end{tabular}




$\begin{array}{llll}\text { tuguan } & \text { 土官 } & \text { Wusa } & \text { 烏撒 } \\ \text { tumin } & \text { 土民 } & \text { xiongwan } & \text { 凶頋 } \\ \text { tumu } & \text { 土目 } & \text { Yan Zhongping } & \text { 嚴中平 } \\ \text { tusi } & \text { 土司 } & \text { Yazhou } & \text { 雅州 } \\ \text { wei } & \text { 畏 } & \text { Yinti } & \text { 胤禵 } \\ \text { Wei Qingyuan } & \text { 韋慶遠 } & \text { yinzhang } & \text { 印章 } \\ \text { Weining } & \text { 威寧 } & \text { Yue Zhongqi } & \text { 岳鍾琪 } \\ \text { Wu Sangui } & \text { 吳三桂 } & \text { Zhenxiong } & \text { 鎮雄 } \\ \text { Wumeng } & \text { 烏蒙 } & \text { zhidao liao } & \text { 知道了 }\end{array}$

\section{Works Cited}

\section{Abbreviations}

DYLZ. Ni Tui, ed. Dian Yun linian zhuan (A record of historical events in Yunnan).

Ca. 1748. Kunming: Yunnan daxue chubanshe, 1992.

GZDYZZZ. Gongzhongdang Yongzhengchao zouzhe (Secret palace memorials of the

Yongzheng period). 32 volumes. Taipei: National Palace Museum, 1977-1980.

GZDZZ. Gongzhongdang zhupi zouzhe (Palace memorials and vermillion rescripts), Minzu shiwu lei (Nationality affairs category). Beijing: Number One Historical Archives.

KXSL. Da Qing lichao shilu (Veritable records of the Qing dynasty) (Kangxi reign, 1661-1722). Taipei: Huawen shuju reprint, 1964.

QSLZ. Qingshi liezhuan (Qing history biographies). 80 juan. 1928. Beijing: Zhonghua shuju reprint, 1987.

SCTZ. Sichuan tongzhi (Comprehensive gazetteer of Sichuan province). Edited by Yang Fangcan, ed. 1816. Chengdu: Sichuan renmin chubanshe reprint, 1984.

SPMYC. Secret Palace Memorials of the Yung-cheng Period: Ch'ing Documents at the National Palace Museum. Shilin: National Palace Museum Press, 1977.

YZSL. Da Qing lichao shilu (Veritable records of the Qing dynasty) (Yongzheng reign, 1723-35). Taipei: Huawen shuju reprint, 1964.

YZZPYZ. Yongzheng zhupi yuzhi (Vermillion rescripts [and palace memorials] of the Yongzheng period). Taipei: Wenhai chubanshe, 1965. 


\section{Other References}

Ceng Xianjiang. "Huxi minzu yu Zang Yi zoulang: yi Mengguzu wei zhongxin de lishi xue kaocha" (A historical investigation of the nomadic peoples of the Tibetan-Yi corridor: a focus on the Mongols). Ph.D. diss., Sichuan University, 2005.

Chen Benming. Zhaotong Yizu shitan (Exploration of the history of the Yi in Zhaotong). Kunming: Yunnan minzu chubanshe, 2001.

Dai Yingcong. The Sichuan Frontier and Tibet: Imperial Strategy in the Early Qing. Seattle: University of Washington Press, 2009.

Darwin, John. Unfinished Empire: The Global Expansion of Britain. New York: Bloomsbury Press, 2012.

Dirks, Nicholas B. The Scandal of Empire: India and the Creation of Imperial Britain. Cambridge, Mass.: Harvard University Press, 2006.

Dongchuan fuzhi (Gazetteer of Dongchuan prefecture). 1761.

Dunstan, Helen. "Safely Supping with the Devil: The Qing State and its Merchants Suppliers of Copper." Late Imperial China 13, no. 2 (1992): 42-81.

Fang Guoyu. Yizu shigao (Draft history of the Yi). Chengdu: Sichuan minzu chubanshe, 1984.

Feng Erkang. Yongzheng zhuan (Biography of the Yongzheng emperor). Beijing: Renmin chubanshe, 1985.

Gramlich-Oka, Bettina. "Shogunal Administration of Copper in the Mid-Tokugawa Period (1670-1720)." In Metals, Monies, and Markets in Early Modern Societies: East Asian and Global Perspectives, ed. Thomas Hirzel and Nanny Kim, 65-105. Berlin: LIT Verlag Münster, 2008.

Giersch, C. Patterson. Asian Borderlands: The Transformation of Qing China's Yunnan Frontier. Cambridge, Mass.: Harvard University Press, 2006.

Gong Yin. Zhongguo tusi zhidu (China's tusi insitution). Kunming: Yunnan renmin chubanshe, 1992.

Guizhou tongzhi, qianshizhi (Comprehensive gazetteer of Guizhou province, a record of early events). 3 volumes. Guiyang: Guizhou renmin chubanshe, 1988.

Guy, R. Kent. Qing Governors and Their Provinces: The Evolution of Territorial Administration in China, 1644-1796. Seattle: University of Washington Press, 2010. 
Harrell, Stevan, "The History of the Yi." In Cultural Encounters on China's Ethnic Frontiers, ed. Stevan Harrell, 63-91. Seattle: University of Washington Press, 1995.

Huang Pei. Autocracy at Work: A Study of the Yung-cheng Period, 1723-1735. Bloomington: Indiana University Press, 1974.

Iwasaki Yoshinori, "Genbun dōza-ki no Nagasaki kaidō to Nagasaki bōeki”" (The Copper Bureau's Role in the Transport of Nagasaki Copper and Nagasaki Trade during the Genbun Period), Sumitomo shiryōkanpō, 34 (2003): 1-42.

Kaske, Elizabeth. "The Price of an Office: Venality, the Individual and the State in $19^{\text {th }}$ Century China." In Metals, Monies, and Markets in Early Modern Societies: East Asian and Global Perspectives, ed. Thomas Hirzel and Nanny Kim, 281-308. Berlin: LIT Verlag Münster, 2008.

Kato Naoto. "Lobzang Danjin's Rebellion of 1723: With a Focus on the Eve of the Rebellion.” Acta Asiatica 64 (1993): 57-80.

Kawakatsu Mamoru. "Shin-Kenryūki Unnandō no kyōun mondai" (Copper transport from Yunnan to Beijing in the Qianlong period of the Qing dynasty). In Min Shin Kōnōsei to kyodaitoshi rensa-Chōkō to Daiungawa (Connections in the Ming-Qing tribute system - the Yangzi River and Grand Canal), ed. Kawakatsu Mamoru, 526-629. Tokyo: Kyūko Shoin, 2009.

Li Shiyu. "Luelun tusi zhidu yu gaitu guiliu" (A brief discussion of the native official [tusi] institution and bureaucratic consolidation). In Zhongguo gudai bianjiang zhengce yanjiu (Research on ancient China's frontier policies), ed. Ma Dazhang, 465-94. Beijing: Zhongguo shehui kexue chubanshe, 1990.

Lin Yaohua [Lin Yueh-hwa]. The Lolo of Liangshan. Translated by Pan Ju-shu. New Haven: HRAF Press, 1961.

Long Xianjun. Zhongguo Yizu tongshi gangyao (Draft history of the Yi nationality in China). Kunming: Yunnan minzu chubanshe, 1993.

Pan Xiangming. "Qingdai Yunnan de kuangye kaifa" (Development of the mining industry in Yunnan during the Qing period). In Qingdai bianjiang kaifa yanjiu (Research on the development of Qing era frontiers), ed. Ma Ruheng and Ma Dazheng, 333-63. Beijing: Zhonghua shehui kexue chubanshe, 1990.

Perdue, Peter C. China Marches West: The Qing Conquest of Central Eurasia. Cambridge, Mass.: The Belknap Press of Harvard University Press, 2005.

Petech, Luciano. China and Tibet in the Early XVIIIth Century: History of the Establishment of a Chinese Protectorate in Tibet. Leiden: E.J. Brill, 1972. 
Qiu Pengsheng. "Shiba shiji Dian tong shichang zhong de guanshang guanxi yu liyi guannian" (Notions of profit and relations between state and merchant in the $18^{\text {th }}$-century Yunnan copper market). Zhongyang yanjiuyuan lishiyuyan yanjiu jikan (Bulletin of the Institute of History and Philology) 72, no. 1 (2001): 49-119.

Satō Hisashi. "Lobzan Danjin no hanlan ni tsuite" (On Lobzan Danjin's revolt). In Chūsei Chibetto shi kenkyu (Studies on the medieval history of Tibet), ed. Satō Hisashi, 383-423. Kyoto: Dohosha, 1986.

Satoshi, Nakajima. "Shinchō no dōsei ni okeru yōdō to tendō" (Qing dynasty copper administration: Japanese copper and Yunnan copper). In Tōyōshigaku Ronshū (Bulletin of oriental research), ed. Nakajima Satoshi, 161-177. Tokyo: Kyūko Shoin, 1988.

She Yize. Zhongguo tusi zhidu (China's tusi institution). Shanghai: Shangwu shuju, 1947.

Smith, Kent Clarke. "Ch'ing Policy and the Development of Southwest China: Aspects of Ortai's Governor-Generalship, 1726-1731." Ph.D. diss., Yale University, 1971.

Ueda, Hiroyuki. Shinchō shihai to kahei seisaku: Shindai zenki ni okeru seisan kyōkyzu seisaku no tenkai (Qing rule and monetary policy: The development of coin supply policy during the early Qing period). Tōkyō: Kyūko Shoin, 2009.

Vogel, Hans Ulrich. “Chinese Central Monetary policy, 1644-1800.” Late Imperial China 8, no. 2 (1987): 1-52.

- "Copper Smelting and Fuel Consumption in Yunnan, Eighteenth to Nineteenth Centuries." In Metals, Monies, and Markets in Early Modern Societies: East Asian and Global Perspectives, ed. Thomas Hirzel and Nanny Kim, 119-70. Berlin: LIT Verlag Münster, 2008.

Wei Caixia. "Qingchao juanjian zhidu jiqi yingxiang" (System of jiansheng degree purchasing and its influence during the Qing dynasty). Guizhou wenshi congkan (Guizhou historical studies) No. 4 (2006): 58-62.

Wei Qingyuan and Lu Su. "Qingdai qianqi kuangye zhengce de yanbian" (Development of mining policy during the early Qing period). Zhongguo shehui jingji shi yanjiu (Research on China's social-economic history) 3, no. 4 (1983): 37-54.

Weinstein, Jodi L. Empire and Identity in Guizhou: Local Resistance to Qing Expansion. Seattle: University of Washington Press, 2013. 
Wu Yue. "Shindai ennō seidō ronkō" (Study of the office purchase system during the Qing dynasty. In Chūgoku Min Shim chihō tōan no kenkyū (Local archival research on Ming-Qing China), ed. Fuma Susumu, 103-30. Kyōto: Kyōto Daigaku Daigakuin Bungaku Kenkyūka Tōyōshi Kenkyūshitsu, 2000.

Xu Daling. Qingdai juanna zhidu (The Qing contribution system). Beijing: Yanjing daxue Hafu Yanjing xueshe, 1950.

Yan Zhongping. Qingdai Yunnan tongzheng kao (Study of copper administration in Yunnan during the Qing period). Beijing: Zhonghua shuju, 1957.

Yang Yuda. "Qingdai zhongqi (1726-1855) niandai Dian dongbei de tongye kaifa yu huanjing bianqian (Development of copper mining and environmental change in northeast Yunnan during the early Qing period, 1726-1855). Zhongguoshi yanjiu (Chinese Historical Research) (2004): 157-74.

Yunnan tongzhi (Comprehensive gazetteer of Yunnan Province). Yengišan (Yin Jishan). 1736.

Zhang, Lawrence Lok Cheung. "Power for a Price: Office Purchase, Elite Families, and Status Maintenance in Qing China." PhD diss., Harvard University, 2010. 